\title{
REPRESENTASI KONFLIK DALAM NOVEL JAKARTA VIGILANTE KARYA VICTORIA A. LESTARI
}

\author{
Endah Subekti ${ }^{1)}$ \\ Fahrudin 1) \\ 1) STKIP PGRI Trenggalek \\ endahsubekti42@gmail.com
}

\begin{abstract}
ABSTRAK: Penelitian ini bertujuan memperoleh gambaran objektif tentang representasi konflik sosial dan representasi konflik batin tokoh utama dalam novel "Jakarta Vigilante" karya Victoria A. Lestari. Penelitian ini bersifat deskriptif dan menggunakan metode dokumentasi untuk mengumpulkan data. Data penelitian berupa unit-unit teks dalam novel "Jakarta Vigilante" karya Victoria yang mencerminkan pokok-pokok masalah dalam variabel penelitian. Hasil penelitian ini meliputi representasi konflik sosial tokoh utama berupa perwakilan pertentangan tokoh utama dengan tokoh lain terdiri dari seseorang mempunyai niat untuk menegakkan keadilan tetapi dihalangi, seseorang mengancam orang lain karena tidak ingin rencananya gagal, seseorang cekcok dengan orang lain karena membuat masalah, perwakilan pertentangan tokoh utama dengan suatu kelompok terdiri dari seseorang ingin menyelamatkan orang lain namun dihalangi beberapa orang, seseorang ingin membalaskan dendamnya, seseorang yang balas dendamnya dihalangi oleh sekelompok orang. Representasi konflik batin tokoh utama berupa perwakilan pertentangan pilihan tokoh utama tidak sesuai dengan kenyataan terdiri dari seseorang tidak bisa menerima kenyataan yang sudah terjadi, seseorang berusaha mencoba mentupi perasaannya, seseorang yang keputusannya tidak ingin diragukan, perwakilan kecemasan tokoh utama dalam menghadapi permasalahan terdiri dari seseorang khawatir rencananya terancam gagal, seseorang cemas karena bingung memikirkan langkah untuk melanjutkan rencananya, seseorang cemas karena takut kehilangan seseorang yang dicintainya.
\end{abstract}

Kata kunci : Representasi, Tokoh Utama, Konflik, Novel, Vigilante

ABSTRACT: This study aims to know the social conflict representation and inner conflict representation of the main character in the "Jakarta Vigilante" novel by Victoria A. Lestari. This research is descriptive and using documentation method to collect data. The research data is a unit of text in Victoria's novel "Jakarta Vigilante" which reflects the principal in the research variable. The results of this study include the representation of the main character's social conflict in the form of representatives of the main character's conflict with other characters consisting of someone who has the intention to uphold justice but is prevented, someone threatens others because they do not want his plans to fail, someone bickers with others for making problems, representatives of the character's conflict the main thing with a group consists of someone wants to save another person but is blocked by some people, someone wants to take revenge, someone whose revenge is blocked by a group of people. Representation of the main character's inner conflict in the form of a representative conflict of choice of the main character is not in accordance with reality consists of someone can not accept the reality that has happened, someone tries to cover their feelings, someone whose decision does not want to be doubted, the representation of the main character's anxiety in dealing with problems consists of someone worried the plan is threatened with failure, someone is worried because they are confused thinking about the steps to continue their plan, someone is worried because they are afraid of losing someone they love.

Keywords: Representation, The main character, Conflict, Novel, Vigilante.

\section{PENDAHULUAN}

Novel dapat diartikan sebagai suatu karangan berbentuk prosa yang mengandung rangkaian cerita kehidupan seseorang dengan orang lain di sekelilingnya dengan 
menonjolkan watak dan sifat pelaku. Novel merupakan suatu karya imajinatif yang memuat berbagai cerita kehidupan yang dialami seseorang dengan orang lain maupun dengan lingkungannya. Novel terdiri atas unsur intrinsik dan unsur ekstrinsik. Kedua unsur inilah yang banyak disebut para kritikus dalam rangka mengkaji atau membicarakan novel pada umunya. Unsur intrinsik adalah unsur-unsur yang membangun karya sastra itu sendiri. Unsur intrinsik sebuah novel adalah unsur-unsur yang secara langsung turut serta membangun cerita. Unsur-unsur intrinsik ini meliputi alur, tema, tokoh dan penokohan, latar, sudut pandang, gaya bahasa, dan amanat (Nurgiyantoro, 2013).

Konflik merujuk pada pengertian sesuatu yang bersifat tidak menyenangkan yang terjadi dan atau dialami oleh tokoh-tokoh cerita, yang jika tokoh-tokoh itu mempunyai kebebasan untuk memilih, mereka tidak akan memilih peristiwa itu menimpanya Meredith \& Fitzgerald (dalam Nurgiyantoro, 2013). Bentuk konflik sebagai bentuk peristiwa dapat dibedakan menjadi dua kategori yaitu konflik eksternal dan konflik internal Stanton (dalam Nurgiyantoro, 2013).

Konflik eksternal adalah konflik yang terjadi antara seorang tokoh dengan sesuatu yang di luar dirinya. Konflik eksternal dibedakan menjadi dua kategori yaitu konflik fisik dengan konflik sosial Jones (dalam Nurgiyantoro, 2013). Sedangkan konflik internal yaitu konflik yang terjadi dalam hati dan pikiran dalam jiwa seorang tokoh. Konflik internal ini meliputi konflik kejiwaan atau konflik batin.

Tokoh adalah orang-orang yang ditampilkan dalam suatu karya naratif. Berdasarkan peran dan pentingnya tokoh dibedakan menjadi dua yaitu tokoh utama dan tokoh tambahan (Nurgiyantoro, 2013). Tokoh utama adalah tokoh yang diutamakan penceritaannya dalam novel yang bersangkutan. Sedangkan tokoh tambahan adalah tokoh yang hanya menjadi pelengkap dalam cerita.

Representasi merupakan sebuah proses ataupun keadaan yang dijadikan sebagai suatu perwakilan terhadap sebuah sikap maupun perbuatan dari seseorang, sekelompok orang dan golongan tertentu di dalam sebuah lingkungan. Novel ini lebih menekankan adanya konflik sosial dan konflik batin yang dialami tokoh utama. Hal inilah yang membuat peneliti ingin fokus menganalisis representasi konflik sosial dan representasi konflik batin yang dialami tokoh utama dalam novel Jakarta Vigilante.

Berdasarkan uraian di atas maka rumusan masalah dalam penelitian ini adalah (1) Bagaimanakah representasi konflik sosial tokoh utama dalam Novel Jakarta Vigilante karya Victoria A. Lestari? (2) Bagaimanakah representasi konflik batin tokoh utama dalam Novel Jakarta Vigilante karya Victoria A. Lestari?. Adapun tujuan penelitian ini adalah untuk mendapatkan gambaran objektif kedua lingkup sasaran tersebut. 


\section{METODE PENELITIAN}

Penelitian kualitatif adalah penelitian yang menghasilkan prosedur analisis yang tidak menggunakan prosedur analisis statistik atau cara kuantifikasi lainnya (Moleong, 2016: 6). Peneliti kualitatif sebagai human instrumen, berfungsi menerapkan fokus penelitian, memilih informan sebagai sumber data, melakukan pengumpulan data, menilai kualitas data, analisis data, menafsirkan data dan membuat kesimpulan atas temuannya (Sugiyono, 2017).

Metode deskriptif adalah penelitian yang memaparkan dan menjelaskan variabel penelitian secara objektif. Data yang dianalisis berupa kata-kata tertulis dan bukti-bukti kutipan cerita novel. Metode deskriptif termasuk metode yang paling banyak digunakan dalam studi penelitian pendidikan.

Metode yang digunakan adalah metode dokumentasi. Metode pengumpulan data dokumentasi yaitu dengan mencari data mengenai hal-hal atau variabel yang berupa catatan, transkrip, surat kabar, majalah, dan sebagainya (Arikunto, 2014: 274). Melalui metode ini data-data yang termuat dalam novel dikumpulkan sebagai perbendaharaan data untuk dapat digunakan sebagai bukti atau keterangan dalam melakukan pengkajian data selanjutnya yang sudah terkumpul itu dapat dianalisis. Aktivitas dalam analisis data kualitatif dilakukan secara interaktif dan berlangsung secara terus-menerus sampai tuntas, sehingga datanya sudah jenuh. Aktivitas dalam analisis data yaitu, reduksi data, penyajian data dan penarikan kesimpulan (Sugiyono, 2017). Penetapan keabsahan data diperlukan teknik pemeriksaan. Untuk memperoleh temuan data sesuai dengan kenyataan hasil penelitian dapat dilakukan dengan tiga teknik yaitu perpanjangan pengamatan, ketekunan pengamatan, dan pembahasan dengan yang lebih kompeten.

\section{HASIL DAN PEMBAHASAN}

Berdasarkan paparan data pada representasi konflik sosial ditemukan data sebagai berikut (1) perwakilan pertentangan antara tokoh utama dengan tokoh lain dan (2) perwakilan pertentangan tokoh utama dengan suatu kelompok.

Tokoh utama terbukti ada niat untuk menegakkan keadilan tapi dihalangi sebagaimana pada nomor urut 14 halaman 68 berikut.

"Mau apa kamu? Minggir atau kamu akan menyesal." Tiara melempar pisau kepada orang yang mengancamnya namun meleset. (14/RKS/68)

Data di atas merupakan data yang menjelaskan bahwa Tiara mengalami pertentangan dengan orang lain yang menghalangi rencananya. Sesuai dengan teori (Nurgiyantoro, 2013) mengemukakan bahwa "Konflik sosial adalah konflik yang disebabkan kontak sosial antar manusia, yang antara lain berwujud masalah perburuan, penindasan, percekcokan, peperangan atau kasus-kasus hubungan sosial lainnya." 
Dari data di atas dapat disimpulkan bahwa seseorang yang mempunyai niat untuk menegakkan keadilan tetapi ada yang menghalangi dan disitulah terjadi perwakilan pertentangan yang melibatkan tokoh utama dengan tokoh lain.

Tokoh utama terbukti mengancam orang lain karena tidak ingin rencananya gagal sebagaimana pada nomor urut 16 halaman 111 berikut.

Tiara mendorong Danar ke dinding dan menutup mulutnya. "Danar, kamu bisa pergi sekarang kalau kamu gak suka pekerjaanтu, tapi kalau kamu membocorkan pertemuan tadi, mereka yang akan mengejarmu." (16/RKS/111)

Data di atas merupakan data yang menjelaskan bahwa Tiara mengalami pertentangan dengan orang lain karena tidak ingin rencananya gagal. Sesuai dengan teori (Nurgiyantoro, 2013) mengemukakan bahwa "Konflik sosial adalah konflik yang disebabkan kontak sosial antar manusia, yang antara lain berwujud masalah perburuan, penindasan, percekcokan, peperangan atau kasus-kasus hubungan sosial lainnya". Dari data di atas dapat disimpulkan bahwa seseorang mengancam orang lain karena ia tidak ingin rencananya gagal dan disitulah terjadi perwakilan pertentangan yang melibatkan tokoh utama dengan tokoh lain.

Tokoh utama terbukti cekcok dengan orang lain yang membuat masalah dengannya sebagaimana pada nomor urut 1 halaman 20 berikut.

Dasar brengsek! Serunya. Ia menatap wajah anak muda itu dengan tatapan kejam.

“ Ke mana ia lari? Kenapa nggak ada yang kejar?”. Raymond gemeteran.” Dia mabuk. Lalu kami berantem. Gue bilang kalau nggak suka sama gue yaudah putus aja. (1/RKS/20)

Data di atas merupakan data yang menjelaskan bahwa Tiara mengalami pertentangan dengan orang lain karena orang lain membuat masalah dengannya. Sesuai dengan teori (Nurgiyantoro, 2013) mengemukakan bahwa "Konflik sosial adalah konflik yang disebabkan kontak sosial antar manusia, yang antara lain berwujud masalah perburuan, penindasan, percekcokan, peperangan atau kasus-kasus hubungan sosial lainnya".

Dari data di atas dapat disimpulkan bahwa seseorang cekcok dengan orang lain yang membuat masalah dengannya dan disitulah terjadi perwakilan pertentangan yang melibatkan tokoh utama dengan tokoh lain. Tokoh utama terbukti ingin menyelamatkan orang lain tapi dihalangi oleh sekelompok orang sebagaimana pada nomor urut 5 halaman 25 berikut.

"Brengsek kalian!Lepaskan dia!Jangan sentuh Angela! Kalau dia sampai kenapa- kenapa, aku pastikan kalian semua menderita. (5/RKS/25)

Data di atas merupakan data yang menjelaskan bahwa Tiara mengalami pertentangan dengan suatu kelompok. Tiara (tokoh utama) terus berusaha menyelamatkan Angela tetapi tidak berhasil karena dikeroyok oleh sekelompok preman. Sesuai dengan 
teori (Nurgiyantoro, 2013) mengemukakan bahwa "Konflik sosial adalah konflik yang disebabkan kontak sosial antar manusia, yang antara lain berwujud masalah perburuan, penindasan, percekcokan, peperangan atau kasus-kasus hubungan sosial lainnya."

Dari data di atas dapat disimpulkan bahwa seseorang yang ingin menyelamatkan orang lain namun dihalangi oleh beberapa orang dan disitulah terjadi perwakilan pertentangan yang melibatkan tokoh utama dengan suatu kelompok.

Tokoh utama terbukti ingin balas dendam sebagaimana pada nomor urut 8 halaman 33 berikut.

"Pokoknya aku ingin mereka merasakan apa yang dirasakan Angela. Sebagai pembalasan dendamku." (8/RKS/33)

Data di atas merupakan data yang menjelaskan bahwa Tiara mengalami pertentangan dengan suatu kelompok. Tiara (tokoh utama) berniat untuk balas dendam kepada segerombolan preman yang sudah memperkosa Angela. Sesuai dengan teori (Nurgiyantoro, 2013) mengemukakan bahwa "Konflik sosial adalah konflik yang disebabkan kontak sosial antar manusia, yang antara lain berwujud masalah perburuan, penindasan, percekcokan, peperangan atau kasus-kasus hubungan sosial lainnya."

Dari data di atas dapat disimpulkan bahwa seseorang yang ingin membalaskan dendamnya terhadap sekelompok preman yang sudah memperkosa adik sepupunya dan disitulah terjadi perwakilan pertentangan yang melibatkan tokoh utama dengan suatu kelompok. Tokoh utama terbukti ingin balas dendam tapi dihalangi sekelompok orang sebagaimana pada nomor urut 13 halaman 44 berikut.

"Siapa kalian? Apa mau kalian?." Dari balik semak dan pepohonan muncul

empat orang pria yang mengepung dan menyerang Tiara. (13/RKS/44)

Data di atas merupakan data yang menjelaskan bahwa Tiara mengalami pertentangan dengan suatu kelompok. Tiara (tokoh utama) di kepung dan di serang oleh kelompok preman yang berniat untuk menghentikan rencana balas dendamnya. Sesuai dengan teori (Nurgiyantoro, 2013) mengemukakan bahwa "Konflik sosial adalah konflik yang disebabkan kontak sosial antar manusia, yang antara lain berwujud masalah perburuan, penindasan, percekcokan, peperangan atau kasus-kasus hubungan sosial lainnya."

Dari data di atas dapat disimpulkan bahwa seseorang yang ingin membalaskan dendamnya tetapi dihalangi oleh sekelompok preman dan disitulah terjadi perwakilan pertentangan yang melibatkan tokoh utama dengan suatu kelompok.

Berdasarkan paparan data pada representasi konflik batin ditemukan data sebagai berikut (1) perwakilan pertentangan pilihan tokoh utama tidak sesuai dengan kenyataan dan (2) perwakilan kecemasan tokoh utama dalam menghadapi permasalahan.

Tokoh utama terbukti tidak bisa menerima kenyataan yang sudah terjadi sebagaimana pada nomor urut 1 halaman 32 berikut.

"Ini semua salahku. Harusnya aku tidak membiarkannya sendiran." Tangisnya parau. Tiara tidak menyangka ini akan terjadi. (1/RKB/32) 
Data di atas merupakan data yang menjelaskan bahwa Tiara mengalami pertentangan bahwa pilihan tokoh tidak sesuai dengan kenyataan, yaitu Tiara (tokoh utama) berusaha untuk menutupi hatinya yang hancur tetapi tidak bisa ketika mengingat adik sepupunya telah tiada. Sesuai dengan teori (Nurgiyantoro, 2013) mengemukakan bahwa "Konflik batin adalah konflik yang terjadi dalam hati dan pikiran, dalam jiwa seorang tokoh atau tokoh-tokoh dalam cerita."

Dari data di atas dapat disimpulkan bahwa seseorang yang tidak bisa menerima kenyataan yang sudah terjadi dan disitulah terjadi perwakilan pertentangan yang melibatkan pilihan tokoh utama tidak sesuai dengan kenyataan.

Tokoh utama terbukti berusaha menutupi perasaannya sebagaimana pada nomor urut 20 halaman 209 berikut.

Ia memutar rekaman tersebut, ia menahan napas menyaksikan gambar berjalan

adik sepupunya sambil berusaha agar matanya tak berkaca-kaca. (20/RKB/209)

Data di atas merupakan data yang menjelaskan bahwa Tiara mengalami pertentangan bahwa pilihan tokoh tidak sesuai dengan kenyataan, yaitu Tiara memilih menahan untuk tidak terlihat sedih ketika melihat rekaman cctv itu. Sesuai dengan teori (Nurgiyantoro, 2013) mengemukakan bahwa "Konflik batin adalah konflik yang terjadi dalam hati dan pikiran, dalam jiwa seorang tokoh atau tokoh-tokoh dalam cerita."

Dari data di atas dapat disimpulkan bahwa seseorang yang berusaha mencoba mentupi perasaannya dan disitulah terjadi perwakilan pertentangan yang melibatkan pilihan tokoh utama tidak sesuai dengan kenyataan.

Tokoh utama terbukti keputusannya tidak ingin diragukan sebagaimana pada nomor urut 6 halaman 45 berikut.

"Non Tiara, sebaiknyakamu gak ikut campur dengan urusan mereka, karena mereka sangat berbahaya.” ujar Pak Alfred. (6/RKB/45)

Data di atas merupakan data yang menjelaskan bahwa Tiara mengalami pertentangan bahwa pilihan tokoh tidak sesuai dengan kenyataan, yaitu Tiara memilih untuk mencari tahu dalang dibalik kejadian kematian Angela tetapi pada kenyataannya Pak Alfred malah melarang Tiara. Sesuai dengan teori (Nurgiyantoro, 2013) mengemukakan bahwa "Konflik batin adalah konflik yang terjadi dalam hati d an pikiran, dalam jiwa seorang tokoh atau tokoh-tokoh dalam cerita."

Dari data di atas dapat disimpulkan bahwa seseorang yang keputusannya tidak ingin diragukan oleh siapapun dan disitulah terjadi perwakilan pertentangan yang melibatkan pilihan tokoh utama tidak sesuai dengan kenyataan.

Tokoh utama terbukti khawatir rencananya terancam gagal sebagaimana pada nomor urut 15 halaman 129 berikut.

Tiara menatap layar ponselnya dengan gusar. Sesekali ia memejamkan mata dan mengusap dahinya. "Pak Alfred aku butuh bantuanmu." (15/RKB/129) 
Data di atas merupakan data yang menjelaskan bahwa tokoh utama mengalami kecemasan dalam menghadapi permasalahan yaitu Tiara (tokoh utama) gusar karena di penthousenya ternyata diam-diam disadap seseorang. Sesuai dengan teori (Nurgiyantoro, 2013) mengemukakan bahwa "Konflik batin adalah konflik yang terjadi dalam hati dan pikiran, dalam jiwa seorang tokoh atau tokoh-tokoh dalam cerita."

Dari data di atas dapat disimpulkan bahwa seseorang yang khawatir rencananya terancam gagal dan disitulah terjadi perwakilan pertentangan yang melibatkan kecemasan tokoh utama dalam menghadapi permasalahan.

Tokoh utama terbukti bingung memikirkan langkah selanjutnya sebagaimana pada nomor urut 9 halaman 70 berikut.

"Mereka tahu aku berlatih. Mereka mungkin tahu rencana aplikasi tersebut. Mereka mungkin tak tahu aku berencana turun ke jalan sebagai vigilante. Tapi kalau mereka tahu itu apa yang harus aku lakukan?" (9/RKB/70)

Data di atas merupakan data yang menjelaskan bahwa tokoh utama mengalami kecemasan dalam menghadapi permasalahan yaitu Tiara cemas ketika dia di ancam oleh kelompok Macan Hitam yang mungkin sudah mengetahui rencananya. Sesuai dengan teori (Nurgiyantoro, 2013) mengemukakan bahwa "Konflik batin adalah konflik yang terjadi dalam hati dan pikiran, dalam jiwa seorang tokoh atau tokoh-tokoh dalam cerita."

Dari data di atas dapat disimpulkan bahwa seseorang yang cemas karena bingung memikirkan langkah untuk melanjutkan rencananya dan disitulah terjadi perwakilan pertentangan yang melibatkan kecemasan tokoh utama dalam menghadapi permasalahan. Tokoh utama terbukti cemas karena takut kehilangan orang yang dicintainya sebagaimana pada nomor urut 26 halaman 259 berikut.

Tiba-tiba rasa rindu memuncak di dadanya, bercampur dengan rasa cemas dan takut kehilangan. (26/RKB/259)

Data di atas merupakan data yang menjelaskan bahwa tokoh utama mengalami kecemasan dalam menghadapi permasalahan yaitu Tiara cemas dan khawatir karena takut terjadi apa-apa dengan Bagus yang akan menjalankan misinya menyusup menjadi anggota Macan Hitam. Sesuai dengan teori (Nurgiyantoro, 2013) mengemukakan bahwa "Konflik batin adalah konflik yang terjadi dalam hati dan pikiran, dalam jiwa seorang tokoh atau tokoh-tokoh dalam cerita."

Dari data di atas dapat disimpulkan bahwa seseorang yang cemas karena takut kehilangan seseorang yang dicintainya dan disitulah terjadi perwakilan pertentangan yang melibatkan kecemasan tokoh utama dalam menghadapi permasalahan. 


\section{KESIMPULAN}

Berdasarkan kesimpulan pada bab I sampai bab $\mathrm{V}$, sebagai penutup dari uraian penelitian ini dapat ditarik kesimpulan yang disajikan secara berurutan sesuai dengan yang dijadikan rumusan masalah (1) representasi konflik sosial tokoh utama dalam novel "Jakarta Vigilante" karya Victoria A. Lestari dan (2) representasi konflik batin tokoh utama dalam novel "Jakarta Vigilante" karya Victoria A. Lestari.

Representasi konflik sosial yang terjadi terdiri dari perwakilan pertentangan tokoh utama dengan tokoh lain dan perwakilan pertentangan tokoh utama dengan suatu kelompok. Perwakilan pertentangan tokoh utama dengan tokoh lain yakni berupa seseorang yang mempunyai niat untuk menegakkan keadilan tetapi ada yang menghalangi, seseorang mengancam orang lain karena ia tidak ingin rencananya gagal, seseorang cekcok dengan orang lain yang membuat masalah dengannya. Perwakilan pertentangan tokoh utama dengan suatu kelompok yakni berupa seseorang yang ingin menyelamatkan orang lain namun dihalangi oleh beberapa orang, seseorang yang ingin membalaskan dendamnya, seseorang yang balas dendamnya dihalangi oleh atau sekelompok orang.

Representasi konflik batin dalam novel Jakarta Vigilante yang meliputi perwakilan pertentangan pilihan tokoh utama tidak sesuai dengan kenyataan, dan perwakilan kecemasan tokoh utama dalam menghadapi permasalahan. Pertentangan pilihan tokoh utama tidak sesuai dengan kenyataan yakni berupa seseorang yang tidak bisa menerima kenyataan yang sudah terjadi, seseorang yang berusaha mencoba mentupi perasaannya, seseorang yang keputusannya tidak ingin diragukan oleh siapapun. Perwakilan kecemasan tokoh utama dalam menghadapi permasalahan yakni berupa seseorang yang khawatir rencananya terancam gagal, seseorang yang cemas karena bingung memikirkan langkah untuk melanjutkan rencananya, seseorang cemas karena takut kehilangan seseorang yang dicintainya.

\section{DAFTAR RUJUKAN}

Aminuddin. 2015. Pengantar Apresiasi Karya Sastra. Bandung: Sinar Baru Algesindo.

Arikunto, Suharsimi. 2014. Prosedur Penelitian Suatu Pendekatan Praktik. Jakarta: PT Rineka Cipta.

Dudi Sabil Iskandar, Rini Lestari. 2016. Mitos Jurnalis. Yogyakarta: Penerbit Andi.

Moleong, J. Lexy. 2016. Metode Penelitian Kualitatif. Bandung: PT Remaja Rosdakarya.

Nurgiyantoro, Burhan. 2013. Teori Pengkajian Fiksi. Yogyakarta: Gadjah Mada University Press.

Puspita, Weni. 2018. Manajemen Konflik. Yogyakarta: Deepublish.

Ratna, Nyoman Kutha. 2015. Teori, Metode, dan Teknik Penelitian Sastra. Yogyakarta: Pustaka Pelajar.

Stanton, Robert. 2012. Teori Fiksi. Yogyakarta: Pustaka Pelajar. 
STKIP PGRI Trenggalek. 2020. Pedoman Penulisan Proposal Dan Skripsi Program Sarjana. Trenggalek: STKIP PGRI Trenggalek.

Sugiyono. 2017. Metode Penelitin Kuantitatif, Kualitatif, dan R\&D. Bandung: Alfabeta.

Victoria, A. Lestari. 2019. Jakarta Vigilante. Yogyakarta: Aria Media Mandiri.ormatif, 130-143. 
Volume 4, Nomor 2, Agustus 2020 